\title{
ONLINE LEARNING AND DIGITAL COMPETENCE: UKRAINE AND THE WORLD
}

\author{
Volodymyr Mandragelia \\ Bila Tserkva Institute of Continuous Professional \\ Education of State Institution of Higher \\ Education "University of Educational Management" \\ National Academy of Educational Sciences of Ukraine \\ str. Levanevsky, 52/4, Bila Tserkva, Kyiv region, 09108, Ukraine, \\ mandra09@gmail.com, https://orcid.org/0000-0003-0807-5309
}

\begin{abstract}
The article is devoted to strengthening the role and importance of online learning and digital competence of teachers and students in the context of globalization and accelerating scientific and technological progress. A comparative analysis of the development of ICT, relevant electronic devices and the introduction of open online courses in the world is done. The main difficulties, shortcomings and achievements in the process of accelerating the dynamics and scale of application of online and distance learning during the lockdown period caused by the coronavirus pandemic are defined. The examples of Ukraine and the European Union show a significant difference between the countries of the world in terms of the development of material and technical base of educational institutions, digital infrastructure, access to high-quality and high-speed Internet, readiness of teachers and students to study in new conditions. There is a significant gap between global scientific and technological development and digital competence of citizens. Based on the use of historical, logical, comparative methods, principles and laws of dialectics argues the need for a deeper and more systematic theoretical understanding of current trends in ICT, rapid improvement of digital competence, especially the teaching staff. The importance of introducing in-depth, systematic and systematic research in Ukraine to assess the available technical resources, quality and prospects of digital infrastructure, the level of digital competence of citizens, the dynamics of online training courses, the impact of the social environment on education. The subject of analysis and strategic decision-making in the field of national digital policy should be relevant social, political, economic and technological problems in the country, improving the legal framework, technical re-equipment of educational institutions of all levels, increasing motivation, especially teaching staff for self-improvement and digital competence.

Key words: online learning, distance learning, online courses, digital competence, ICT, educational institutions, pandemic.
\end{abstract}

\section{В. А. Мандрагеля}

Білоцерківський інститут безперервної професійної освіти ДВНЗ «Університет управління освітою» Національної академії освітніх наук України, вул. Леваневського, 52/4, м. Біла Церква, Київська обл., Україна, 09108

\section{ОНЛАЙН НАВЧАННЯ ТА ЦИФРОВА КОМПЕТЕНТНІСТЬ: УКРАЇНА ТА СВІТ}

Стаття присвячена питанням посилення ролі та значення онлайн навчання та цифрової компетенції педагогів та учнів в умовах глобалізації та прискорення науково-технічного прогресу. Здійснено порівняльний аналіз розвитку IKT, відповідних електронних девайсів та запровадження відкритих онлайн курсів в світі. Зазначені основні труднощі, недоліки та досягнення у процесі прискорення динаміки і масштабів застосування онлайн та дистанційного навчання в період карантину, спричиненого пандемією короновірусу. На прикладах України та країн Європейського Союзу доводиться значна різниця між країнами світу з огляду розвинутості матеріально-технічної бази навчальних закладів, цифрової інфраструктури, доступу до якісного і швидкісного Інтернету, готовності викладачів та учнів до занять в нових умовах. Констатується суттєвий розрив між глобальним науково-технічним розвитком та цифровою компетентністю громадян. На основі використання історичного, логічного, порівняльного методів, принципів та законів діалектики аргументується необхідність більш глибокого і системного теоретичного осмислення сучасних тенденцій розвитку IKT, швидкого покращання

(C) Volodymyr Mandragelia, 2021 
2021 Випуск/ Issue 48

цифрової компетентності, насамперед викладацького складу. Підкреслюється важливість запровадження в Україні глибоких, систематичних та системних досліджень щодо оцінки наявних технічних ресурсів, якості і перспектив розвитку цифрової інфраструктури, рівня цифрової компетенції громадян, динаміки запровадження навчальних онлайн курсів, впливу соціального оточення на сферу освіти. Предметом аналізу та прийняття стратегічних рішень у сфері національної цифрової політики мають стати дотичні соціальні, політичні, економічні та технологічні проблеми в країні, удосконалення нормативно-правової бази, технічне переоснащення навчальних закладів усіх рівнів, підвищення мотивації, насамперед педагогічного складу на самовдосконалення та підвищення цифрової компетентності.

Ключові слова: онлайн навчання, дистанційне навчання, онлайн курси, цифрова компетентність, IKT, навчальні заклади, пандемія.

\section{В. А. Мандрагеля}

Белоцерковский институт непрерывного профессионального образования ГВУЗ «Университет управления образованием» Национальной академии образовательных наук Украины, ул. Леваневского, 52/4,

г. Белая Церковь, Киевская обл., Украина, 09108

\section{ОНЛАЙН ОБУЧЕНИЕ И ЦИФРОВАЯ КОМПЕТЕНТНОСТЬ: УКРАИНА И МИР}

Статья посвящена вопросам усиления роли и значения онлайн обучение и цифровой компетенции педагогов и учащихся в условиях глобализации и ускорения научно-технического прогресса. Осуществлен сравнительный анализ развития ИКТ, соответствующих электронных девайсов и внедрение открытых онлайн курсов в мире. Указаны основные трудности, недостатки и достижения в процессе ускорения динамики и масштабов применения онлайн и дистанционного обучения в период карантина, вызванного пандемией короновируса. На примерах Украины и стран Европейского Союза доказывается значительная разница между странами мира с учетом развитости материально-технической базы учебных заведений, цифровой инфраструктуры, доступа к качественному и скоростного Интернета, готовности преподавателей и учащихся к занятиям в новых условиях. Констатируется существенный разрыв между глобальным научно-техническим развитием и цифровой компетентностью граждан. На основе использования исторического, логического, сравнительного методов, принципов и законов диалектики аргументируется необходимость более глубокого и системного теоретического осмысления современных тенденций развития ИКТ, быстрого улучшения цифровой компетентности, прежде всего преподавательского состава. Подчеркивается важность проведения в Украине глубоких, систематических и системных исследований по оценке имеющихся технических ресурсов, качества и перспектив развития цифровой инфраструктуры, уровня цифровой компетенции граждан, динамики внедрения учебных онлайн курсов, влияния социального окружения на сферу образования. Предметом анализа и принятия стратегических решений в сфере национальной цифровой политики должны стать социальные, политические, экономические и технологические проблемы в стране, совершенствование нормативно-правовой базы, техническое переоснащение учебных заведений всех уровней, повышение мотивации, прежде всего педагогического состава в контексте самосовершенствования и повышения цифровой компетентности.

Ключевые слова: онлайн обучение, дистанционное обучение, онлайн курсы, цифровая компетентность, ИКТ, учебные заведения, пандемия.

Introduction. The relevance of the article is due to the development of high-quality innovative education systems that promote the formation of effective skills for work, personal development and citizenship, help to adapt in the transit period to the digital and green economy. Of particular importance is the digital competence of teachers and students as ICTs are dynamically improved, online and distance learning is being introduced on a large scale in a pandemic.

Analysis of recent publications. Many works of domestic scientists (A. Andreev, V. Bykov, N. Bolyubash, A. Khutorskaya, N. Korsunska, V. Kukharenko, T. Murashchenko, E. Polat, V. Soldatkin, O. Tikhomirov, V. Vashchenko, N. Zhevakina) and foreign experts (T. Adebisi, A. Andujar, R. Frazze,
M. Henda, O. Oyeleke, D. Painter, A. Rossett, R. Schank, P. Valiathan,) are devoted to general theoretical issues of distance education and accompanying concepts. K. Helm, S. Huber, S. Litvinov, N. Morse, O. Spivakovsky, M. Stigmar, M. Zhaldak, Y.Zhuk considered the effective use of digital technologies in the educational process. O. Bazelyuk, O. Bilous, L. Chernikova, N. Dementievska, F. Khan, K. Novela-Garcia, S. Redeker, N. Soroko, O. Spirin, I. Vorotnikova studied the digital competence of a pedagogical worker. The impact of Covid-19 on education was studied by F. Biagi, O. Chandasiri, P. Costa, G. Di Pietro, T. Jensen, Z. Karpiński, H. Land, G. Mariononi, J. Mazza, A. Simakhova, N. Stukalo and others. Many scientific materials and 
documents of the UN, OECD, EU, Ukraine, nongovernmental organizations contain recommendations for improving education in a pandemic and ICT development.

The purpose of the article is a comparative analysis of the quality of online education and digital competence of citizens in countries of European Union, USA and Ukraine in a pandemic.

Results and discussion. The development of digital technologies has extremely high dynamics. This can be illustrated by the data on sales of electronic devices. Shipment of tablets, laptops and desktop PCs worldwide in 2010 was 377 million units. The number of annual sales during $2011-2020$ exceeded 400 million units and will be stable before 2025 [6]. Even higher sales rates were observed among smartphones. The first ones appeared in 2007 and sold 132.22 million units by the end of the year. However, the number of smartphone sales grew rapidly and after 2016 (excluding 2020 - 1.37872 billion) annually exceeded 1.5 billion. $38 \%$ of the world's total population owned a smart device in 2018, and the smartphone penetration rate has continued climbing, reaching $46.5 \%$ percent in 2020 [20].

The development of ICT was well ahead of their introduction into the field of education. The Institute of Strategy and Management (USA) has begun developing online courses in 1981. Next was the University of Phoenix (USA) that has launching real-time training in 1989. However, a qualitative breakthrough came in 2011 when Stanford University launched the Massive Open Online Courses (MOOCs). At the end of 2015, they were introduced by 142 universities worldwide. At the same time, the first practical results of using MOOC did not live up to expectations. A 2013 study noted that only around 5\% of students across seventeen Coursera MOOCs completed their courses, and that those who were most successful in this type of online class were those who had already completed a high level of education, and not those at whom MOOCs were originally aimed [17].

However, the effectiveness of online learning has grown steadily, despite the first mistakes and shortcomings. Since then, more than 900 universities around the world have launched free online courses. In addition to the larger global platforms (Coursera, edX, FutureLearn), many national governments around the world have launched their own country-specific MOOC platforms, including India, Italy, Israel, Mexico and Thailand. By the end of 2020, more than 180 million learners had signed up for at least one MOOC [23].
But, this was not a qualitative breakthrough in the introduction of the online learning system. One of the three principal laws of dialectics is the law of the transformation of quantity into quality, and vice versa. The number of accumulated electronic devices allowed taking a decisive step in modernizing the learning process. That is, a critical mass of e-learning tools has been achieved. A trigger was needed to encourage a quality transition to new forms of learning. This happened in connection with Covid-19. On March 11, 2020, the World Health Organization announced that the epidemic situation caused by the coronavirus is becoming a pandemic. At the time of writing, according to the Dashboard by the Center for Systems Science and Engineering (CSSE) at Johns Hopkins University (JHU), it has sickened more than 140 million people worldwide. More than three million people have died so far [11].

Covid-19 has had an unprecedented impact on education around the world. As of April 2, 2020, the number of students who were forced to stay at home due to the closure of educational institutions at all levels reached a peak - 1, 484 billion people ( $86.3 \%$ of the total) in 194 countries. In Ukraine, this figure was 6,785 thousand people. Schools in the United States, India, Indonesia, Iraq, Iran, Malaysia, and the vast majority of South American countries were closed for an average of more than 41 weeks as of mid-April 2021. In Ukraine, the duration of the complete closure of educational institutions was 19 weeks [12].

Within a few weeks, about 20,000 higher education institutions had ceased normal operation, sending home close to 200 million students. Many institutions switched to online classes after only a few days of preparation [22]. The ability to respond to school closures changes dramatically with level of development: for instance, during the second quarter $2020,86 \%$ of children in primary education have been effectively out of school in countries with low human development - compared with just $20 \%$ in countries with very high human development [26]

Experts from World Bank group noted that transition to online learning and teaching was comparatively easy for those countries that had invested in the sector and approached digitalization in a strategic way precrisis (for example, Denmark, Estonia, Finland, France, Germany). But countries like Bulgaria, Georgia, Ukraine, and Uzbekistan may thus face difficulties in the full implementation of distance learning. There were also problems that united countries regardless of economic and technological development. 
Among global challenges, the following are related to the online infrastructure: weakness of internet connection and internet speed in many countries; high prices for a good internet connection; absence of computers/laptops/tablets/ smartphones that support online teaching and learning; many online instruments, platforms, and websites crashed when an unexpectedly high number of clients connected to them [7].

In particular, M. Fedorov, Deputy Prime Minister - Minister of Digital Transformation of Ukraine, announced on July 30, 2020 that more than 5.5 million Ukrainians do not have access to high-quality fixed Internet [4]. A rather difficult situation is observed in schools. At the beginning of the current school year, there were more than 16.3 thousand of them in Ukraine. $60 \%$ of schools (9773) have an Internet connection using fiber-optic technologies, and 40\% (6544) are not connected at all. Of these, 2,000 schools are located in settlements that do not have any optical provider [3]. The Ministry of Digital Transformation of Ukraine plans to connect more than 3,000 Ukrainian villages with a population of approximately 1 million people to the optical Internet by the end of 2021 [5]. These rates of digital infrastructure improvement appear to be extremely low.

In addition to purely technical aspects, the readiness of teachers and students of educational institutions of all levels for online learning proved to be a very important issue. For instance, 2020 public consultation results in countries of EU show: almost $60 \%$ of the respondents had not used distance and online learning before the crisis; $95 \%$ consider that the COVID-19 crisis marks a point of no return for how technology is used in education and training; respondents say that online learning resources and content need to be more relevant, interactive and easy to use; over $60 \%$ felt that they had improved their digital skills during the crisis and more than $50 \%$ of respondents want to do more [13].

These data indicate a dangerous lag of digital competencies not only of teachers and students, but also of all citizens from the dynamic development of ICT. So, Council of EU Recommendation of 22 May 2018 on key competences for lifelong learning noted that $44 \%$ of the Union's population have low or no digital skills (19\%) [10]. However, there are positive exceptions. For instance, in 1985, computer technology or "tietotekniikka" in Finnish, was introduced as an elective subject in the Finnish curriculum. Furthermore, Finland ranks fifth on the digital scoreboard of the European Commission, with its citizens having basic skillsin all of the five core digital competencies: information, communication, content-creation, problem solving, and safety. Additionally, Statistic Finland (2018) reports revealed that $89 \%$ of the Finnish citizens (ranging in age between 16 and 89), interact with digital technologies and use the Internet on a daily basis [18].

However, in general, the conceptual understanding of the development of digital competencies of citizens lags far behind technical progress. Only in 2013 did the European Commission's Joint Research Center start developing the DigComp digital competence system. У 2016. була оприлюднена оновлена версія - (DigComp 2.0: The Digital Competence Framework for Citizens) [27]. In 2017, the following option was presented DigComp 2.1: The Digital Competence Framework for Citizens with eight proficiency levels and examples of use [8]. The competences had a five areas: information and data literacy; communication and collaboration; digital content creation; safety; problem solving.

There was an even greater delay in Ukraine. The relevant Digital Competence Framework for Citizens based on DigComp 2.1 of the European Union was prepared only at the end of March 2021. According to the press office of the Ministry of Digital Transformation of Ukraine, this framework contains 4 dimensions, 6 areas, 30 competencies and 6 levels of digital skills [1].

Chronic delay of Ukraine from the leading countries of the world, in particular, the EU, is observed in the level of assessment and monitoring of digital competencies of teachers. For instance, in 2017, the European Framework for the Digital Competence of Educators (DigCompEdu) appeared in the EU. The six DigCompEdu areas focus on different aspects of educators' professional activities: professional engagement; digital resources; teaching and learning; assessment; empowering learners; facilitating learners' digital competence [21]. There are no such documents in Ukraine yet. The sphere of national education is much inferior to the developed countries of the world, given the existing platforms for digital self-development of teachers. According to a survey among teachers and students in 2018, when asked «How did you improve your digital competence?», 43.1\% of respondents answered «I improved my skills on my own» [19].

Unfortunately, systematic in-depth research on the introduction of distance learning during lockdown has not yet been conducted in Ukraine. However, online surveys show that $55.53 \%$ of 
schools had a problem with distance learning because they did not have such experience before, so they were not ready to learn during lockdown, as did $47.5 \%$ of teachers who had not previously used distance learning technology in their pedagogical activities [2].

Ukrainians have a relatively poor knowledge of English. This limits the range of use of distance and online courses to improve digital competence. In 2020 Ukraine ranked only 44th among the 100 countries surveyed in terms of English language proficiency [14].

However, from our point of view, the main mistake in the national sphere of education in a pandemic is to focus on a fairly narrow range of tasks. The main one is the effective use of digital technologies in the process of transferring knowledge (information) from teacher to student. Establishing effective communication, receiving feedback, working together on common projects, sharing experiences between students is left out of consideration.

Ukraine has not yet conducted large-scale sociological researches of changes in the motivation of students to study in a pandemic. One of the important indicators is the number of hours spent by students in preparation for classes. For example, a survey conducted in Germany, Austria and Switzerland in April 2020 shows that 18\% of students reported low effort (i.e. less than 9 hours per week. Assuming a study week of 5 days, this corresponds to less than 2 hours a day spent on academic matters [16, p. 247-248]. The UK Office for National Statistics conducted a study on the effects of coronavirus on the system and educational outcomes in mid-April 2020, when a strict lockdown was introduced. When asked by students of vocational and technical educational institutions how much time a week they spend preparing for classes in a pandemic compared to the usual mode of study, $17 \%$ said that $20-30$ hours less, $14 \%-15-20$ hours less , 15\% - 10-15 hours less, $15 \%$ 5-10 hours less and 7\% 2-5 hours less.
Thus, $68 \%$ of respondents confirmed a decrease in motivation to study [9, p. 7].

Issues such as the general climate in the family, support from students by parents, siblings and relatives, technical equipment and the spatial situation at home require in-depth and comprehensive research. To this should be added a systematic analysis of the conditions of study in the school, its capabilities given the quality and quantity of technical equipment. In particular, in the United States after the pandemic, only RAND Corporation studied teachers' perceptions of inequities in students' internet access and participation in remote learning [24], inform policy and education practice related to educators' and students' needs during the COVID-19 pandemic [15], how teachers educating students with disabilities during the pandemic [25]. And this is by no means a complete list of issues that require systematic research in Ukraine.

Conclusions. The pandemic crisis has posed challenging challenges to the education system around the world. They require vigorous efforts to develop digital infrastructure, improve the digital competence of citizens, create comfortable conditions for online learning in the workplace and at home, strengthen the motivational levers to master the necessary competencies. The existing gap between the development of ICT and the effective use of digital technologies in the educational process must be promptly closed. It is necessary to develop digital competencies of teachers and students, taking into account the prospects of labor market formation, new innovations in technological progress. Ukraine needs a national program for the development of digital infrastructure, technical re-equipment of educational institutions, training and retraining of teachers. An important task is the development of research centers with a focus on systematic research of the conditions and opportunities for the use of digital technologies in education and other spheres of public life.

\section{СПИСОК ВИКОРИСТАНИХ ДЖЕРЕЛ ТА ЛІТЕРАТУРИ:}

1. Мінцифра оприлюднює Рамку цифрової компетентності для громадян. Прес-офіс Міністерства цифрової трансформації, 30 березня 2021 p. URL: https://thedigital.gov.ua/news/mintsifra-oprilyudnyue-ramkutsifrovoi-kompetentnosti-dlya-gromadyan?fbclid=IwAR3EmNSz2IDRQCC2WyrZfGde5kvwnYaQrdnnIpVy4ysYc bbJ1rQvwPVIdOw (дата звернення: 12.04.2021)

2. Радчук О. Навчальний рік в онлайні: про наслідки змін в освіті у період карантину. Слово і діло. 15 січня 2021. URL: https://www.slovoidilo.ua/2021/01/15/kolonka/aleksandr-radchuk/suspilstvo/navchalnyj-rikonlajni-pro-naslidky-zmin-osviti-period-karantynu (дата звернення: 11.04.2021) 
2021 Випуск/ Issue 48

3. Ржеутська Л. Коронавірус, локдаун та онлайн-навчання: якими є реалії української школи. Deutsche Welle. 19.01.2021. URL: https://www.dw.com/uk/koronavirus-lokdaun-ta-onlain-navchannia-yakymy-yerealii-ukrainskoi-shkoly/a-56273278 (дата звернення: 17.04.2021)

4. Федоров М. Понад 5,5 мільйонів українців не можуть отримати якісний фіксований інтернет. Українська правда. 30 липня 2020. URL: https://www.pravda.com.ua/columns/2020/07/30/7261199/ (дата звернення: 12.04.2021)

5. Цього року до оптичного інтернету підключать більше 3000 сіл - Федоров. Економічна правда. 14 квітня 2021. URL: https://www.epravda.com.ua/news/2021/04/14/672992/ (дата звернення: 11.04.2021)

6. Alsop T. Shipment forecast of tablets, laptops and desktop PCs worldwide from 2010 to 2024. Statista. Feb 18, 2021. - URL: https://www.statista.com/statistics/272595/global-shipments-forecast-for-tablets-laptops-anddesktop-pcs/ (Last accessed: 12.04.2021).

7. Arnhold N.,Brajkovic L., Nikolaev D.,Zavalina P.TertiaryEducationand COVID-19:Impactand MitigationStrategies in Europe and Central Asia. URL:http://documents1.worldbank.org/curated/en/783451590702592897/ COVID-19-Impact-on-Tertiary-Education-in-Europe-and-Central-Asia.pdf (Last accessed: 14.04.2021).

8. Carretero S., Vuorikari R. and Punie Y. DigComp 2.1: The Digital Competence Framework for Citizens with eight proficiency levels and examples of use, EUR $28558 \mathrm{EN}$, doi:10.2760/38842, 48 p.

9. Coronavirus and the impact on measures of UK government education output. London : Office for National Statistics, 13 May 2020. 9 pp.

10. Council Recommendation of 22 May 2018 on key competences for lifelong learning (2018/C 189/01) URL: https://eur-lex.europa.eu/legal-content/EN/TXT/PDF/?uri=CELEX:32018H0604(01)\&from=LT (Last accessed: 14.04 .2021$)$

11. COVID-19 Dashboard by the Center for Systems Science and Engineering (CSSE) at Johns Hopkins University (JHU). URL: https://coronavirus.jhu.edu/map.html (Last accessed: 13.04.2021)

12. COVID-19Impacton Education. UNESCO,10/04/2021.URL: https://en.unesco.org/covid19/educationresponse. (Last accessed: 12.04.2021)

13. Digital Education Action Plan (2021-2027). European Commission. URL: https://ec.europa.eu/education/ education-in-the-eu/digital-education-action-plan_en (Last accessed: 15.04.2021).

14. EF English Proficiency Index. A Ranking of 100 Countries and Regions by English Skills. EF EPI, 2020. 52 pp.

15. Hamilton L.S., Grant D., Kaufman J.H., Diliberti M.K., Schwartz H.L., Hunter G.P., Setodji C.M., Young C.J. COVID-19 and the State of K-12 Schools. Results and Technical Documentation from the Spring 2020 American Educator Panels COVID-19 Surveys., Santa Monica, Calif.: RAND Corporation, 2020. 34 pp.

16. Huber S.G., Helm C. COVID-19 and schooling: evaluation, assessment and accountability in times of crisesreacting quickly to explore key issues for policy, practice and research with the school barometer. Educational Assessment, Evaluation and Accountability. 2020. Volume 32. P. 237-270.

17. International Trends in Higher Education 2015. Katherine Benson (Ed.). Oxford : University of Oxford, 2016. 26 pp.

18. Khan F. Digital Competence Assessment Across Generations A Finnish Sample Using the Digcomp Framework. International Journal of Digital Literacy and Digital Competence. 2019. Volume 10. Issue 2. P. 15 - 28.

19. Kuzminska O., Mazorchuk M., Morze N., Pavlenko V., Prokhorov A. Digital Competency of the Students and Teachers in Ukraine: Measurement, Analysis, Development Prospects. URL: http://ceur-ws.org/Vol-2104/ paper_169.pdf (Last accessed: 16.04.2021)

20. O’Dea S. Smartphone sales worldwide 2007-2021. Statista. Mar 31, 2021- URL: https://www.statista.com/ statistics/263437/global-smartphone-sales-to-end-users-since-2007/ (Last accesses 14.04.2021)

21. Redecker C. European Framework for the Digital Competence of Educators: DigCompEdu. Punie, Y. (ed). EUR 28775 EN. Publications Office of the European Union, Luxembourg, 2017, ISBN 978-92-79-73494-6, doi:10.2760/159770, JRC107466

22. Salmi J. COVID's Lessons for Global Higher Education. Lumina Foundation. November 2020. URL: https://www. luminafoundation.org/wp-content/uploads/2020/11/covids-lessons-for-global-higher-education.pdf

23. Shah D., Pickard L. Massive List of MOOC Providers Around The World. Class Central. Feb 3rd, 2021. URL: https://www.classcentral.com/report/mooc-providers-list/ (Last accesses 14.04.2021)

24. Stelitano L., Doan S., Woo A., Diliberti M.K., Kaufman J.H., Henry D. The Digital Divide and COVID-19. Teachers' Perceptions of Inequities in Students' Internet Access and Participation in Remote Learning. RAND Corporation. URL: https://www.rand.org/pubs/research_reports/RRA134-3.html (Last accesses 17.04.2021)

25. Stelitano L., Mulhern C., Feistel K., Gomez-Bendaña H. How Are Teachers Educating Students with Disabilities During the Pandemic? RAND Corporation. URL: https://www.rand.org/pubs/research_reports/RRA1121-1. html (Last accesses 15.04.2021). 
26. United Nations Development Programme (UNDP). COVID-19 and human development: Assessing the crisis, envisioning the recovery. 2020 Human Development Perspectives, 2020, New York: UNDP. URL: http://hdr. undp.org/en/hdp-covid (Last accesses 14.04.2021)

27. Vuorikari R., Punie Y., Carretero G.S., Van den Brande G. (2016). DigComp 2.0: The Digital Competence Framework for Citizens. Update Phase 1: The Conceptual Reference Model. Luxembourg Publication Office of the European Union. EUR 27948 EN. doi:10.2791/11517

\section{REFERENCES:}

1. Mintsyfra opryliudniuie Ramku tsyfrovoi kompetentnosti dlia hromadian. Prec-ofis Ministerstva tsyfrovoi transformatsii, 30 bereznia 2021. URL: https://thedigital.gov.ua/news/mintsifra-oprilyudnyue-ramkutsifrovoi-kompetentnosti-dlya-gromadyan?fbclid=IwAR3EmNSz2IDRQCC2WyrZfGde5kvwnYaQrdnnIpVy4ysYc bbJ1rQvwPVIdOw (Last accessed: 12.04.2021) [in Ukrainian].

2. Radchuk, O. Navchal'nyj rik v onlajni: pro naslidky zmin v osviti u period karantynu. Slovo i dilo. 15 sichnia 2021. URL: https://www.slovoidilo.ua/2021/01/15/kolonka/aleksandr-radchuk/suspilstvo/navchalnyj-rik-onlajnipro-naslidky-zmin-osviti-period-karantynu (Last accessed: 11.04.2021) [in Ukrainian].

3. Rzheuts'ka, L. Koronavirus, lokdaun ta onlajn-navchannia: iakymy ie realii ukrains'koi shkoly. Deutsche Welle. 19.01.2021. URL: https://www.dw.com/uk/koronavirus-lokdaun-ta-onlain-navchannia-yakymy-ye-realiiukrainskoi-shkoly/a-56273278 (Last accessed: 17.04.2021). [in Ukrainian].

4. Fedorov, M. Ponad 5,5 mil'joniv ukraintsiv ne mozhut' otrymaty iakisnyj fiksovanyj internet. Ukrains'ka pravda. 30 lypnia 2020. URL: https://www.pravda.com.ua/columns/2020/07/30/7261199/ (Last accessed: 12.04.2021). [in Ukrainian].

5. Ts'oho roku do optychnoho internetu pidkliuchat' bil'she 3000 sil - Fedorov. Ekonomichna pravda. 14 kvitnia 2021. URL: https://www.epravda.com.ua/news/2021/04/14/672992/ (Last accessed: 11.04.2021). [in Ukrainian].

6. Alsop, T. (2021). Shipment forecast of tablets, laptops and desktop PCs worldwide from 2010 to 2024. Statista. Feb 18, 2021. URL: https://www.statista.com/statistics/272595/global-shipments-forecast-for-tabletslaptops-and-desktop-pcs/ (Last accessed: 12.04.2021).

7. Arnhold, N., Brajkovic L., Nikolaev D., Zavalina P. (2020) Tertiary Education and COVID-19: Impact and Mitigation Strategies in Europe and Central Asia. URL: http://documents1.worldbank.org/curated/ en/783451590702592897/COVID-19-Impact-on-Tertiary-Education-in-Europe-and-Central-Asia.pdf (Last accessed: 14.04.2021).

8. Carretero, S., Vuorikari, R. and Punie, Y. (2017). DigComp 2.1: The Digital Competence Framework for Citizens with eight proficiency levels and examples of use, EUR $28558 \mathrm{EN}$, doi:10.2760/38842, 48 p.

9. Coronavirus and the impact on measures of UK government education output. (2020). London : Office for National Statistics, 13 May 2020.9 pp.

10. Council Recommendation of 22 May 2018 on key competences for lifelong learning (2018/C 189/01) URL: https://eur-lex.europa.eu/legal-content/EN/TXT/PDF/?uri=CELEX:32018H0604(01)\&from=LT ～(Last accessed: 14.04 .2021$)$

11. COVID-19 Dashboard by the Center for Systems Science and Engineering (CSSE) at Johns Hopkins University (JHU). (2021) URL: https://coronavirus.jhu.edu/map.html (Last accessed: 13.04.2021)

12. COVID-19 Impacton Education.UNESCO,10/04/2021.URL: https://en.unesco.org/covid19/educationresponse. (Last accessed: 12.04 .2021$)$

13. Digital Education Action Plan (2021-2027). European Commission. (2021) URL: https://ec.europa.eu/ education/education-in-the-eu/digital-education-action-plan_en (Last accessed: 15.04.2021).

14. EF English Proficiency Index. A Ranking of 100 Countries and Regions by English Skills. (2020). EF EPI. 52 pp.

15. Hamilton, L.S., Grant, D., Kaufman, J.H., Diliberti, M.K., Schwartz, H.L., Hunte,r G.P., Setodji, C.M., Young, C.J. (2020). COVID-19 and the State of K-12 Schools. Results and Technical Documentation from the Spring 2020 American Educator Panels COVID-19 Surveys., Santa Monica, Calif. : RAND Corporation. 34 pp.

16. Huber, S.G., Helm, C. (2020). COVID-19 and schooling: evaluation, assessment and accountability in times of crises-reacting quickly to explore key issues for policy, practice and research with the school barometer. Educational Assessment, Evaluation and Accountability. Volume 32. P. 237-270.

17. International Trends in Higher Education 2015. (2016). Katherine Benson (Ed.). Oxford : University of Oxford. $26 \mathrm{pp}$.

18. Khan, F. (2019). Digital Competence Assessment Across Generations A Finnish Sample Using the Digcomp Framework. International Journal of Digital Literacy and Digital Competence. 2019. Volume 10. Issue 2. P. 15 - 28. 
2021 Випуск/ Issue 48

19. Kuzminska, O., Mazorchuk M., Morze N., Pavlenko V., Prokhorov A. (2018). Digital Competency of the Students and Teachers in Ukraine: Measurement, Analysis, Development Prospects. URL: http://ceur-ws.org/Vol-2104/ paper_169.pdf (Last accessed: 16.04.2021)

20. O'Dea, S. (2021). Smartphone sales worldwide 2007-2021. Statista. Mar 31, 2021- URL: https://www.statista. com/statistics/263437/global-smartphone-sales-to-end-users-since-2007/ (Last accesses 14.04.2021)

21. Redecker, C. (2017). European Framework for the Digital Competence of Educators: DigCompEdu. Punie, Y. (ed). EUR 28775 EN. Publications Office of the European Union, Luxembourg. ISBN 978-92-79-73494-6, doi:10.2760/159770, JRC107466

22. Salmi, J. (2020) COVID's Lessons for Global Higher Education. Lumina Foundation. November 2020. URL: https:// www.luminafoundation.org/wp-content/uploads/2020/11/covids-lessons-for-global-higher-education.pdf (Last accesses 14.04.2021)

23. Shah, D., Pickard, L. (2021). Massive List of MOOC Providers Around The World. Class Central. URL: https:// www.classcentral.com/report/mooc-providers-list/ (Last accesses 14.04.2021)

24. Stelitano, L., Doan, S., Woo, A., Diliberti, M.K., Kaufman, J.H., Henry,D. (2020). The Digital Divide and CoVID-19. Teachers' Perceptions of Inequities in Students' Internet Access and Participation in Remote Learning. RAND Corporation. URL: https://www.rand.org/pubs/research_reports/RRA134-3.html (Last accesses 17.04.2021)

25. Stelitano, L., Mulhern, C., Feistel, K., Gomez-Bendaña, H. (2021). How Are Teachers Educating Students with Disabilities During the Pandemic? RAND Corporation. URL: https://www.rand.org/pubs/research_reports/ RRA1121-1.html (Last accesses 15.04.2021).

26. United Nations Development Programme (UNDP). COVID-19 and human development: Assessing the crisis, envisioning the recovery. 2020 Human Development Perspectives, 2020, New York: UNDP. URL: http://hdr. undp.org/en/hdp-covid (Last accesses 14.04.2021)

27. Vuorikari, R., Punie Y., Carretero, G. S., Van den Brande, G. (2016). DigComp 2.0: The Digital Competence Framework for Citizens. Update Phase 1: The Conceptual Reference Model. Luxembourg Publication Office of the European Union. EUR 27948 EN. doi:10.2791/11517 